\title{
Pollen morphology of eight tribes of Asteraceae from Universitas Indonesia Campus, Depok, Indonesia
}

\author{
ANDI SALAMAH", RACHMI LUTHFIKASARI, ASTARI DWIRANTI \\ Department of Biology, Faculty of Mathematics and Natural Sciences, Universitas Indonesia. Depok16404, West Java, Indonesia. Tel.: +62-21-7270163, \\ +62-21-78849009, Fax.: +62-21-78849010, `email: salamah@ sci.ui.ac.id
}

Manuscript received: 13 October 2018. Revision accepted: 12 December 2018.

\begin{abstract}
Salamah A, Luthfikasari R, Dwiranti A. 2019. Pollen morphology of eight tribes of Asteraceae from Universitas Indonesia Campus, Depok, Indonesia. Biodiversitas 20: 152-159. Asteraceae is one of the largest flowering plant families in the world consisting of a high diversity of species that possess many macro-morphological characters. Ecological pressures have resulted in this highly varied morphology. Our research aims to describe the pollen morphology of the Asteraceae for species occurring in Depok Campus of Universitas Indonesia. Pollens of 14 species from eight tribes were extracted using acetolysis method and observed under a light microscope. The result showed that pollen unity, shape and pollen surface appeared to be differentiating characters of the Asteraceae from other families, while polarity and symmetry characters can be distinguishing characters at higher levels of the family such as subdivisions. Aperture characters were useful to differentiate between tribes. The shape of pores and size of pollen were not useful in differentiating between tribes, but may differentiate between lower taxa. The results of this study could be used as supporting data for regrouping taxa within the Asteraceae using morphological features.
\end{abstract}

Keywords: Asteraceae, differentiating characters, pollen, species, tribes

\section{INTRODUCTION}

Asteraceae is the second largest flowering plant family after the Orchidaceae comprising herbaceous plants or shrubs (Heywood 1985). The family consists of more than 1.500 genera and 23.000 species (Zavada and Villiers 2000 ) and has many potentials and benefits in areas such as food, pharmacy, agriculture, industry, and ecology (Kew Royal Botanic Garden 2015).

The taxonomy of this plant group has long been studied because of the vast number of species it possesses (Bremer 1987). Cassini (1817) was the first researcher to group Asteraceae members into 19 tribes based on macromorphological characters such as characters on stems, leaves, and flowers. Tribal grouping of the family was also performed by Bentham (1873) who recognized 13 tribes and this classification is still in use today (Bremer 1987). However, the macro-morphological characters alone are not strong determinant characters in the family's tribal classification especially taxa that have traditionally difficult to classify because of highly divergent macromorphological character. This finding is reinforced by the existence of several genera that cannot be placed into a particular tribe, namely Brachylaena, Eremothamnus, Gundelia, Moquinia and Tarchonanthus (Wortley et al. 2007).

The reason for the grouping difficulty was because Asteraceae has an irregular level of high macromorphological characters, as occurs in the genus Adenocaulon that cannot be incorporated into any tribes (Panero and Funk 2008). The irregular level of macromorphological characters was caused by ecological specialization, such as apomixes that was occurred in the family as an adaptation process to environment. The apomictic nature of Asteraceae made the family to have a high degree of adaptation and spread throughout the world except for the Arctic and Antarctica. However, such properties also resulted in changing of the macromorphology, even effecting changes in the number of chromosomes sets that varied between $2 n=2$ to $2 n=120$ (Anderberg et al. 2007 in Jeffrey 2007). Therefore, a stable distinguishing character is required in the classification process of the Asteraceae family. Such stability of character is found in pollen (Wortley et al. 2007).

Wortley et al. (2007) showed that pollen has been used as a data source for the classification of Asteraceae. The characters of pollen became a consideration for revising the phylogenetics of Gundelia and Warioina. In addition, Robinson et al. (2008) has also resurrected the genus Strobocalyx from Gymnanthemum and Vernonia, as well as gave rise to a new genus Tarlmounia based on pollen morphological characters.

Studies on pollen morphology of Asteraceae in Indonesia are still very few. Setyowati (2008) observed the pollen morphology of eight Asteraceae species in Yogyakarta to determine the kinship among them, namely Aster novae-angliae, Cosmos sulphureus, Eupatorium odoratum, Tithonia difersifolia, Tagetes erecta, Tagetes patula, Wedelia prostrata, and Zinnia elegans. Rismayanti et al. (2014) also conducted a study on pollen morphology of Ageratum conyzoides and Eleutheranthera ruderalis in Bogor which give the ecological services as the energy sources for Trigona sp bee. Octavia et al. (2015) described the pollen morphology of 35 species of Asteraceae from 
Malang Raya. Based on those studies, pollen morphology of 41 species of Asteraceae had been recorded, which is still very limited compared to the total number of 132 species recorded from Sumatera (Tjitrosoedirdjo 2002). Studies on pollen morphology of the Asteraceae in Indonesia are, therefore, necessary to be done.

Campus area of Universitas Indonesia (UI) is one of the open green zones in the border area between the Indonesian capital territory, Province of Jakarta, and Depok City of the Province of West Java. Oktarina (2013) observed that there were 21 species of Asteraceae growing in the university areas, whereas Mustaqim (Personal communication, 2015) found 33 species growing scattered in various places on the campus. She described the 21 species including their chromosome numbers (Oktarina 2013; Ambarwati 2015). Nevertheless, studies on morphology and morphometry of pollen have not been executed in UI Campus. Our research aims to describe the pollen morphology of the Asteraceae from UI Campus in Depok. The pollen morphological data will be used to compare the similarity of pollen characteristics within one tribe and/or between species. Furthermore, we have also revealed the ultrastructure of representative species by taking the advantages of Scanning Elecron Microscopy (SEM).

\section{MATERIALS AND METHODS}

\section{Collection of Samples}

The research was performed between OctoberDecember 2015. Flowers of 14 Asteraceae species (Ageratum conyzoides, Bidens pilosa, Chromolaena odorata, Clibadium surinamense, Cyanthillium cinereum, Eclipta prostrata, Elephantopus scaber, Emilia sonchifolia, Porophyllum ruderale, Sonchus arvensis, Sphagneticola trilobata, Synedrella nodiflora, Tridax procumbens, Zinnia elegans) were collected around campus area of Universitas Indonesia (UI). The identification of each species was carried out following the description reported by Oktarina (2013). Pollen samples were collected from three to five flowers from each species; each sample was then put into separate papillote paper for pollen preparation.

\section{Acetolysis stock}

Anhydrous acetic acid $(9 \mathrm{~mL})$ was poured into a dark bottle and then added with $1 \mathrm{~mL}$ of sulfuric. The mixture was then stirred with a stir bar and kept under low light.

\section{Safranin 1\%}

Safranin powder (1 gram) was dissolved in $100 \mathrm{~mL}$ of $96 \%$ alcohol. The solution was then stored in a dark bottle and allowed to stand for 24 hours. The solution was then filtered using Whatman No. 01 filter paper. Subsequently, the $1 \%$ safranin stock solution was stored in a dark bottle at room temperature and ready for use.

\section{Acetolysis of pollen}

Acetolysis of the pollen was performed according to the method described by Wrońska-Pilarek (2015). A collection of pollen grains at the end of an anther was isolated by tapping using a sonde over an object glass, or taken with the help of tweezers and then placed onto an object glass. The grains of pollen were then spilled with 1-2 drops of water. The hot plate was heated to reach $60^{\circ} \mathrm{C}$ prior to the pollen isolation. Then, the samples were heated over the hot plate until $90 \%$ of water was evaporated (about 4-6 minutes). Subsequently, the pollen grains were dripped with 1-2 drops of acetolysis, and the heating was continued until $90 \%$ of the acetolysis was evaporated. After that, the object glass was removed from the heater and the pollen grains were added with 2-3 drops of $96 \%$ ethanol. The impurities trapped in the ethanol solution were cleaned using tissue paper. Later, the safranin dye was taken using a sonde tip and then flattened onto the surface of the pollen. One drop of glycerin was also flattened to the preparation. The samples were then covered with a cover glass and its edges were sealed using transparent nail polish. The pollen sample was ready to be observed under a microscope.

\section{Pollen data observation}

Pollen data observation and measuring were conducted at Universitas Indonesia-Olympus Bioimaging Center (UIOBC) Laboratory, using a light microscope (Olympus Inverted IX73). We observed ten pollens from each flower. The qualitative data (polarity, symmetry, aperture, polar appearance, equatorial appearance and unity of pollen) and the quantitative data (length and diameter of the spines, aperture diameter, polar looks diameter, equator diameter, and the ratio polar/equator) features were analyzed.

\section{Sample preparation and observation using Scanning Electron Microscopy}

Pollen of the representative Asteraceae was fixed with $2.5 \%$ glutaraldehyde in $0.1 \mathrm{M}$ Phosphate Buffer Saline (PBS) pH 7.2 for up to 30 minutes at room temperature, followed with PBS washing three times, 5 minutes each. Samples were then subjected to $\mathrm{OsO}_{4}$ post-fixation for 15 minutes and subsequently dehydrated upon ethanol/water series $(70 \%, 80 \%, 90 \%$, and 100\%), 10 minutes each. Following dehydration, samples were incubated at $-80^{\circ} \mathrm{C}$ overnight, dried by applying freeze-drying method, and finally observed using SEM (FEI) at $80 \mathrm{kV}$.

\section{RESULTS AND DISCUSSION}

\section{Polarity, symmetry, unity of pollen, outer appearance and surface of pollen}

Outer appearance (pollen shape) was obtained by comparing the polar diameter (PD) and equatorial diameter (ED) (Table 1). The classification of pollen shape is determined according to the PD to ED ratio as described by Erdtman (1969). The shape of the pollen is classified according to the ratio of polar and equator diameter. The perlobate shape has the polar to equator diameter ratio of $2: 1$. The equator length of perprolate pollen is half of the polar length. The polar to equator pollen ratio of $4: 8$ up to $6: 8$ is classified as the oblate pollen. While the suboblate has the polar to equator ratio of $6: 8$ up to $7: 8$. The polar to equator ratio of $7: 8$ up to $8: 7,8: 7$ up to $8: 6$, and $8: 6$ to $8: 4$ 
are classified as spheroidal, subprolate and prolate pollen shape respectively. The classification of pollen size is determined according to longest diameter measured: very small $(<10 \mu \mathrm{m})$, small $(10-25 \mu \mathrm{m})$, medium $(25-50 \mu \mathrm{m})$, large $(50-100 \mu \mathrm{m})$, very large $(100-200 \mu \mathrm{m})$, and gigantic (>200 $\mu \mathrm{m})$.

The polar diameter ranged from $33.11 \pm 2.06 \mu \mathrm{m}$ (in Ageratum conyzoides) to $57.25 \pm 5.71 \mu \mathrm{m}$ (in Elephantopus scaber). The equatorial diameter ranged from $32.78 \pm 2.03$ $\mu \mathrm{m}$ (in Ageratum conyzoides) to $57.68 \pm 4.86 \mu \mathrm{m}$ (in Elephantopus scaber). According to Erdtman's grouping (Erdtman 1969), all of the Asteraceae observed in this study had a spheroidal shape.

Table 2 showed the results from qualitative observation on pollen of Asteraceae that grown scattered around UI campus. It appeared that all of the fourteen species of Asteraceae had isopolar characters, radial isopolar symmetry, and monad unit. All pollens of the fourteen species studied here were spheroidal and had an echinate surface. These results were slightly different from the observations of Mbagwu et al. (2008) who found that Chromolaena odorata at Agricultural Garden of Imo State University Owerri, Nigeria had smooth pollen wall.

Table 1. Size and shape of pollen grain of Asteraceae examined

\begin{tabular}{|c|c|c|c|c|c|}
\hline Taxa & PD $(\mu \mathrm{m})$ & $\mathbf{E D}(\mu \mathrm{m})$ & PD/ED & Size & Shape \\
\hline \multicolumn{6}{|l|}{ Tribe Milleriae } \\
\hline Tridax procumbens & $34.57(47.13 \pm 4.51) 56.70$ & $33.82(47.21 \pm 4.99) 55.69$ & $47 / 47$ & Medium & Spheroidal \\
\hline \multicolumn{6}{|l|}{ Tribe Heliantheae } \\
\hline Clibadium surinamense & $35.88(40.75 \pm 3.12) 48.88$ & $33.82(40.19 \pm 3.12) 47.13$ & $41 / 40$ & Medium & Spheroidal \\
\hline Synedrella nodiflora & $35.38(39.67 \pm 2.51) 45.13$ & $34.03(38.99 \pm 2.63) 43.88$ & $40 / 39$ & Medium & Spheroidal \\
\hline Sphagneticola trilobata & $45.38(51.28 \pm 3.42) 59.75$ & $44.88(51.32 \pm 3.40) 58.88$ & $51 / 51$ & Large & Spheroidal \\
\hline Eclipta prostrata & $33.48(39.09 \pm 3.13) 44.22$ & $34.40(38.11 \pm 2.53) 42.88$ & $39 / 38$ & Medium & Spheroidal \\
\hline Zinnia elegans & $39.38(43.99 \pm 2.89) 49.25$ & $39.00(43.43 \pm 2.51) 48.13$ & $44 / 43$ & Medium & Spheroidal \\
\hline \multicolumn{6}{|l|}{ Tribe Eupatorieae } \\
\hline Chromolaena odorata & $31.68(37.81 \pm 3.36) 48.25$ & $32.06(37.49 \pm 3.71) 46.65$ & 38.37 & Medium & Spheroidal \\
\hline Ageratum conyzoides & $29.69(33.11 \pm 2.06) 39.38$ & $29.44(32.78 \pm 2.03) 41.13$ & $33 / 33$ & Medium & Spheroidal \\
\hline \multicolumn{6}{|l|}{ Tribe Tageteae } \\
\hline Porophyllum ruderale & $44.13(53.24 \pm 4.46) 59.50$ & $46.35(53.67 \pm 3.89) 60.88$ & $53 / 54$ & Large & Spheroidal \\
\hline \multicolumn{6}{|l|}{ Tribe Vernonieae } \\
\hline Cyanthillium cinereum & $39.75(45.91 \pm 3.84) 55.13$ & $36.88(45.97 \pm 4.65) 55.00$ & $46 / 46$ & Medium & Spheroidal \\
\hline Elephantopus scaber & $50.50(57.25 \pm 5.71) 72.00$ & $51.50(57.68 \pm 4.86) 70.63$ & $58 / 59$ & Large & Spheroidal \\
\hline \multicolumn{6}{|l|}{ Tribe Coreopsideae } \\
\hline Bidens pilosa & $38.09(42.16 \pm 2.38) 46.39$ & 37.09 (41.24 \pm 2.45$) 42.87$ & $42 / 41$ & Medium & Spheroidal \\
\hline \multicolumn{6}{|l|}{ Tribe Senecioneae } \\
\hline Emilia sonchifolia & $32.43(41.53 \pm 6.42) 53.05$ & $33.82(41.93 \pm 6.34) 52.55$ & $42 / 42$ & Medium & Spheroidal \\
\hline \multicolumn{6}{|l|}{ Tribe Chicorieae } \\
\hline Sonchus arvensis & $31.30(43.22 \pm 4.94) 54.69$ & $36.71(43.46 \pm 4.18) 52.17$ & $43 / 44$ & Medium & Spheroidal \\
\hline
\end{tabular}

Note: PD: Polar Diameter; ED: Equatorial Diameter

Table 2. The comparison of pollen characters between Asteraceae family

\begin{tabular}{|c|c|c|c|c|c|c|c|}
\hline \multirow{2}{*}{ Name of species } & \multirow{2}{*}{ Tribe } & \multirow{2}{*}{ Polarity } & \multirow{2}{*}{ Symmetry } & \multirow{2}{*}{ Unity } & \multicolumn{2}{|c|}{ Outer appearance } & \multirow{2}{*}{ Surface } \\
\hline & & & & & Polar & Equator & \\
\hline Ageratum conyzoides & Eupatorieae & Isopolar & Radialisopolar & Monad & Spheroidal & Spheroidal & Echinate \\
\hline Bidens pilosa & Coreopsideae & Isopolar & Radialisopolar & Monad & Spheroidal & Spheroidal & Echinate \\
\hline Chromolaena odorata & Eupatorieae & Isopolar & Radialisopolar & Monad & Spheroidal & Spheroidal & Echinate \\
\hline Clibadium surinamense & Heliantheae & Isopolar & Radialisopolar & Monad & Spheroidal & Spheroidal & Echinate \\
\hline Cyanthillium cinereum & Vernonieae & Isopolar & Radialisopolar & Monad & Spheroidal & Spheroidal & Echinate \\
\hline Eclipta prostrata & Heliantheae & Isopolar & Radialisopolar & Monad & Spheroidal & Spheroidal & Echinate \\
\hline Elephantophus scaber & Vernonieae & Isopolar & Radialisopolar & Monad & Spheroidal & Spheroidal & Echinate \\
\hline Emilia sonchifolia & Senecioneae & Isopolar & Radialisopolar & Monad & Spheroidal & Spheroidal & Echinate \\
\hline Porophyllum ruderale & Tageteae & Isopolar & Radialisopolar & Monad & Spheroidal & Spheroidal & Echinate \\
\hline Sonchus arvensis & Chicorieae & Isopolar & Radialisopolar & Monad & Spheroidal & Spheroidal & Echinate \\
\hline Sphagneticola trilobata & Heliantheae & Isopolar & Radialisopolar & Monad & Spheroidal & Spheroidal & Echinate \\
\hline Synedrella nodiflora & Heliantheae & Isopolar & Radialisopolar & Monad & Spheroidal & Spheroidal & Echinate \\
\hline Tridax procumbens & Millerieae & Isopolar & Radialisopolar & Monad & Spheroidal & Spheroidal & Echinate \\
\hline Zinnia elegans & Heliantheae & Isopolar & Radialisopolar & Monad & Spheroidal & Spheroidal & Echinate \\
\hline
\end{tabular}


In attempts to see the specificity of Asteraceae characters from other families, we compared them with some other families' characteristics (Table 3). Pollen from some of the family under order Asterales was compared such as Calyceraceae, Goodeniaceae, Campanulaceae, and Menyanthaceae. Asteraceae and Calyceraceae represent a unique biological example with surviving lineages of both the paleotetraploid and paleohexaploid ancestors (Barker et al. 2016). Pollen of Calyceraceae has similarities in polarity, symmetry and microspinulate spines, but different in the shape of pollen. Asteraceae has spheroidal-shaped and macro-echinate pollen, while Calyceraceae has triangular-type and micro-echinate pollen (De Vore et al. 2007). Goodeniaceae also have highly similar pollen characteristic to the Asteraceae with a slight difference in shape ratio (suboblate 6:8-7:8; spheroidal 7:8-8:7; prolate $8: 6-8: 4)$. Menyathaceae has the same polarity, symmetry, and unity character to the Asteraceae but slight difference pollen shape ratio (subprolate 8:7-8:6) and rugulate exine despite being traditionally classified near Gentianaceae (order Gentianales) (Gustaffson et al. 1997). Campanulaceae placed under Asterales order on different clade but showed highly similar pollen morphological character to the Asteraceae (some species has rugulate surface but mostly echinate) (Khansari et al. 2012). The pollen morphological character of families under order Asterales was highly similar because the families were included on Asterales - Campanulales Complex which has a unique character that occurs consistently on described families such as secondary pollen presentation and high accumulation of the polysaccharide inulin (Gustaffson and Bremer 1995). Based on comparisons of some families under order Asterales described, the shape of pollen and pollen surface could be used as distinguishing characters between families.

We also compared the characters of Asteraceae pollen in Campus of Universitas Indonesia with the other distant families. Solanaceae shared the lineages with Asteraceae from paleohexaploid ancestors but no evidence of paleotetraploid ancestors unlike Calyceraceae (Barker et al. 2016), but showed highly similar pollen morphology characteristic beside Solanaceae has striate-verrucate pollen surface. Malvaceae also has similar pollen morphological characteristic to the Asteraceae. Pollen of the Asteraceae was spheroidal and had a sharp tip of spines while Malvaceae pollen was globose and had blunt end spines with pores between spines (Prihatiningsih 2011). In comparisons with the Fabaceae family, especially the genus Acacia genus, we found differences in unity and also the surface of pollen (Al-Watba et al. 2013). Based on comparisons with Solanaceae, Malvaceae, and Fabaceae families, it could be said that the shape of pollen, pollen surface, and the unity of pollen could be used as distinguishing characters between families. The comparison of the Asteraceae family with Pinaceae family showed differences in polarity, symmetry, pollen shape, and pollen surface. The Asteraceae family has an isopolar polarity, radial isopolar symmetry, spheroidal pollen shape, and echinate pollen surface while the Pinaceae family has a heteropolar polarity, asymmetry, prolate-subprolate pollen shape, and verrucate-rugulate pollen surface (Feuer 1990; Song et al. 2012). Asteraceae with Pinaceae have different subdivision groups. Asteraceae lies in the subdivision of Angiospermae, whereas Pinaceae is in the subdivision of Gymnospermae. Therefore, polarity and symmetry characters can be distinguishing characters at higher levels of the family such as subdivisions (Table 3 ).

\section{Apertures, pores, and size}

Under the light microscope, the apertures of Asteraceae in Universitas Indonesia Campus were revealed to be tricolporate and fenestrate (Figure 1). It is in accordance with previous report stating that the pollen of Asteraceae was basically tricolporate (Blackmore et al. 2009). Polyporate condition in the Asteraceae (tribe Vernonieae) had also been found (Robinson and Skvarla 2014). Among 14 species studied, the combination of tricolporate and tetracalporate pollen aperture were also found of the Tridax procumbens, Ageratum conyzoides, and Emilia sonchifolia. The ultrastructure appearance examined under SEM further described the differences between those apertures as shown in Figure 2.

Table 3. The comparison of family characters of Asteraceae family with other families

\begin{tabular}{|c|c|c|c|c|c|}
\hline Family & Polarity & Symmetry & Unity & $\begin{array}{c}\text { Outer appearance } \\
\text { (pollen shape) }\end{array}$ & Surface \\
\hline Asteraceae & Isopolar & Radial isopolar & Mona & Spheroidal & Echinate (macro- \\
\hline Calyceraceae (De Vore et.al. 2007) & Isopolar & Radial isopolar & Monad & Triangular & Echinate (micro-size thorn) \\
\hline Campanulaceae (Khansari et al. 2012) & Isopolar & Radial isopolar & Monad & Spheroidal & Echinate-rugulate \\
\hline Goodeniaceae (Gustaffson et al. 1997) & Isopolar & Radial isopolar & Monad & Prolate - Suboblate & Echinate (micro-size thorn) \\
\hline Menyanthaceae (Gustaffson et al. 1997) & Isopolar & Radial isopolar & Monad & Prolate-Subprolate & Rugulate \\
\hline Solanaceae (Perveen and Qaiser 2007) & Isopolar & Radial isopolar & Monad & Spheroidal & Striate-verrucate \\
\hline Malvaceae (Prihatiningsih 2011) & Isopolar & Radial isopolar & Monad & Globose & Baculate (torn with blunt end) \\
\hline Fabaceae (Acacia sp.) (Al-Watba et al. 2013) & Isopolar & Radial isopolar & Polyad & Spheroidal & Psilate-microreticulate \\
\hline Pinaceae (Song et al. 2012) & Heteropolar & - & Monad & Prolate-subprolate & Verrucate-rugulate \\
\hline
\end{tabular}



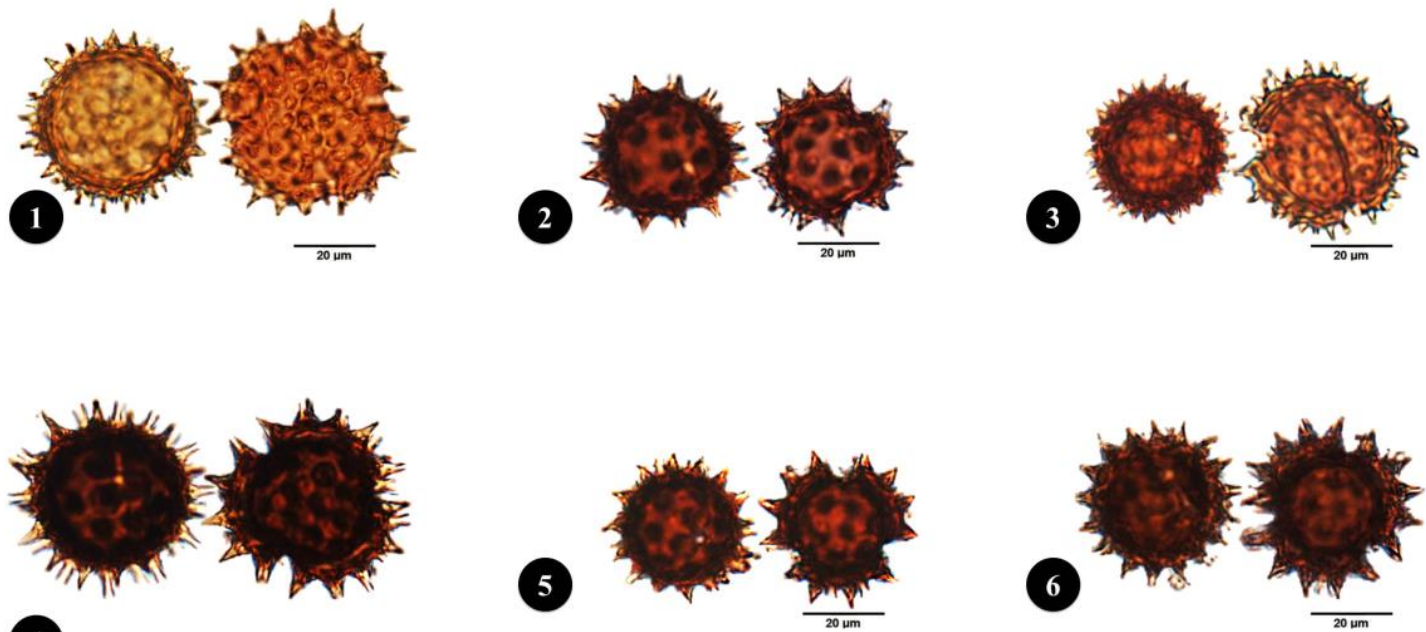

4
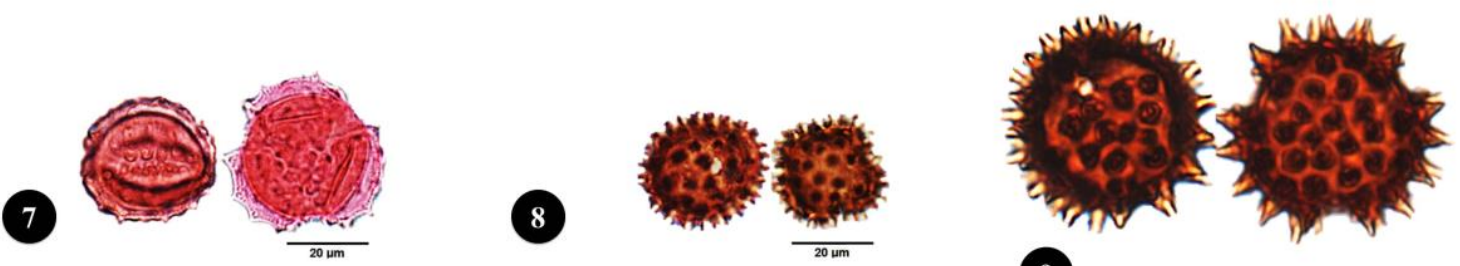

9
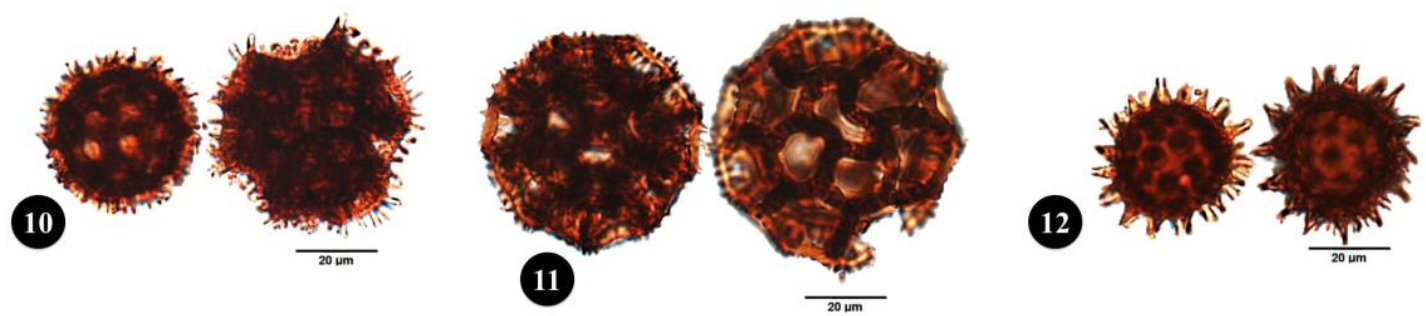

13
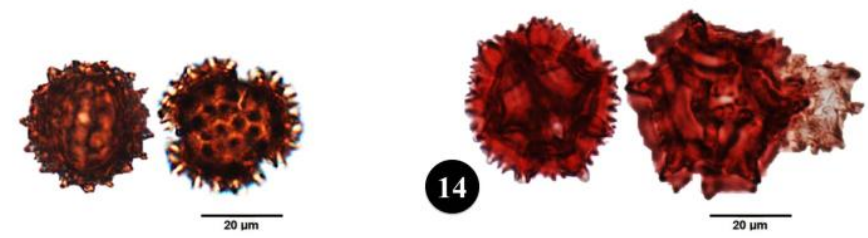

Figure 1. Pollen grains (left: equatorial view, right: polar view) of: 1. Tridax procumbens, 2. Clibadium surinamense, 3. Synedrella nodiflora, 4. Sphagneticola trilobata, 5. Eclipta prostrate, 6. Zinnia elegans, 7. Chromolaena odorata, 8. Ageratum conyzoides, 9. Porophyllum ruderale, 10. Cyanthillium cinereum, 11. Elephantopus scaber, 12. Bidens pilosa, 13. Emilia sonchifolia, 14. Sonchus arvensis

Figure 2.A. depicted the ultrastructure of Sonchus arvensis pollen representing the detailed fenestrate aperture. The diameter of the pollen was ranging from 22 to $29 \mu \mathrm{m}$. The polar area of this species was relatively small, with few isolated central spines. The grains were echinate with spines $\pm 2 \mu \mathrm{m}$ high and $\pm 2 \mu \mathrm{m}$ in diameter at the base. In contrast, the tricolporate aperture of Porophyllum ruderale characterized by noticeably wide colpi is shown at Figure 2.B. Spheroidal, circular in equatorial view, the diameter was 23-28 $\mu \mathrm{m}$, and the surface of this species showed that the polar areas were very extensive, with 20-25 spines. The grains were echinate with spines $\pm 3,5 \mu \mathrm{m}$ high and $\pm 3,5 \mu \mathrm{m}$ in diameter at the base. Tridax procumbens (Fig. 2.C.) had tricolporatetetracolporate aperture and the pollen diameter was 7-10 times smaller $( \pm 3 \mu \mathrm{m})$ than that of Sonchus arvensis and Porophyllum ruderale. The spines were 0.5-0.7 $\mu \mathrm{m}$ high and $\pm 0.5 \mu \mathrm{m}$ in diameter. 

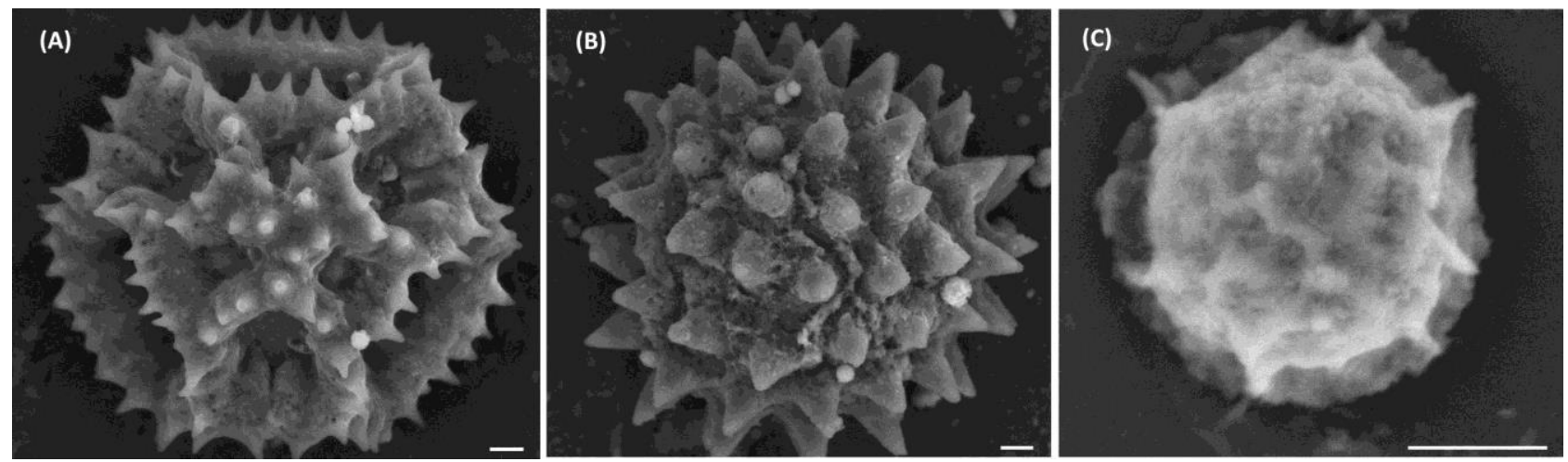

Figure 2. Pollen grains of Sonchus arvensis (A), Porophyllum ruderale (B), and Tridax procumbens (C) showing the fenestrate, tricolporate and tricolporate-tetracolporate apertures respectively. Bars: $2 \mu \mathrm{m}$

Table 4. Exine data pollen grains of Asteraceae examined (AD - Aperture Diameter)

\begin{tabular}{|c|c|c|c|c|c|}
\hline Taxa & Aperture & $\begin{array}{l}\text { Number of } \\
\text { apertures }\end{array}$ & $\mathbf{A D}(\mu \mathrm{m})$ & Pore shape & Pore diameter $(\mu \mathrm{m})$ \\
\hline \multicolumn{6}{|l|}{ Tribe Milleriae } \\
\hline Tridax procumbens & $\begin{array}{l}\text { Tricolporate- } \\
\text { Tetracolporate }\end{array}$ & $3-4$ & $4.88(6.77 \pm 1.64) 12.09$ & Rectangular & $4.04(4.61 \pm 1.03) 5.76$ \\
\hline \multicolumn{6}{|l|}{ Tribe Heliantheae } \\
\hline Clibadium surinamense & Tricolporate & 3 & $5.24(6.6 \pm 1.78) 10.13$ & Circular & $2.39(4.72 \pm 1.42) 6.22$ \\
\hline Synedrella nodiflora & Tricolporate & 3 & $3.72(4.96 \pm 1.09) 6.58$ & Circular & $2.4(3.68 \pm 0.91) 5.14$ \\
\hline Sphagneticola trilobata & Tricolporate & 3 & $4.83(5.93 \pm 1.16) 8.16$ & Circular & $2.37(3.42 \pm 0.74) 5.2$ \\
\hline Eclipta prostrata & Tricolporate & 3 & $3.33(5.19 \pm 1.18) 6.89$ & Rectangular & $1.89(3.32 \pm 1.39) 6.56$ \\
\hline Zinnia elegans & Tricolporate & 3 & $3.78(5.47 \pm 1.21) 8.05$ & Circular & $2.63(3.61 \pm 0.59) 4.64$ \\
\hline \multicolumn{6}{|l|}{ Tribe Eupatorieae } \\
\hline Chromolaena odorata & Tricolporate & - & $2.61(5.25 \pm 1.45) 7.65$ & - & - \\
\hline Ageratum conyzoides & $\begin{array}{l}\text { Tricolporate-- } \\
\text { Tetracolporate }\end{array}$ & $3-4$ & $2.81(4.03 \pm 1.21) 6.24$ & Circular & $2.55(3.15 \pm 0.4) 3.56$ \\
\hline \multicolumn{6}{|l|}{ Tribe Tageteae } \\
\hline $\begin{array}{l}\text { Porophyllum ruderale } \\
\text { Tribe Vernonieae }\end{array}$ & Tricolporate & 3 & $3.63(7.33 \pm 1.96) 10.34$ & Rectangular & $3(4.81 \pm 1.03) 6.38$ \\
\hline Cyanthillium cinereum & Fenestrate & - & $5.94(10.76 \pm 3.55) 13.68$ & Circular & $2.39(3.78 \pm 0.96) 4.85$ \\
\hline $\begin{array}{l}\text { Elephantopus scaber } \\
\text { Tribe Coreopsideae }\end{array}$ & Fenestrate & - & - & - & $3.10(4.45 \pm 1.68) 6.38$ \\
\hline $\begin{array}{l}\text { Bidens pilosa } \\
\text { Tribe Senecioneae }\end{array}$ & Tricolporate & 3 & $4.02(4.46 \pm 0.69) 5.50$ & Circular & 3.39 \\
\hline Emilia sonchifolia & $\begin{array}{l}\text { Tricolporate-- } \\
\text { Tetracolporate }\end{array}$ & $3-4$ & $2.89(5.22 \pm 1.54) 8.91$ & Circular & $2.99(4.55 \pm 1.09) 6.04$ \\
\hline $\begin{array}{l}\text { Tribe Chicorieae } \\
\text { Sonchus arvensis }\end{array}$ & Fenestrate & - & 5.13 & Circular & $2.94(4.32 \pm 1.13) 6.54$ \\
\hline
\end{tabular}

Not only providing aperture differences, but the observation using SEM also showed the three-dimensional images and clear differences of the surface structure of the three observed species. Although Asteraceae had an echinate (macro-size thorn) surface as reported before, the exine ornamentation variation of each observed species was distinct. The spinules (conical-shaped spines forming the echinate appearance of the intercolpoid regions of the exine) of Porophyllum ruderale and Sonchus arvensis appeared to have different heights. The former had rough relief exhibiting broad-based spinules that were $3 \mu \mathrm{m}$ higher than the latter. On the other hand, Tridax procumbens showed relatively low spinule frequency. These results proved that the spatial arrangements of the exine components of these three species were varied and much more clearly discernible by analyzing the SEM micrograph. Furthermore, the advantages of SEM in investigating the complex exines of the pollens of the three species had also been assessed in this study due to its high magnification, resolution, and great depth of field. The pollen ultrastructure analysis of other Asteraceae species using SEM had also previously been reported such as of the tribe Barnadesioideae, Cichorieae, and Vernonieae (Zhao et al. 2000; Wang et al. 2009; Wortley et al. 2012; Robinson 
and Skvarla 2014).

To further elucidate the aperture information of the Asteraceae found in UI campus, we gained the quantitative data by measuring the aperture diameter as well as pore diameter as shown in Table 4. The aperture diameter ranged from $4.03 \pm 1.21 \mu \mathrm{m}$ (in Ageratum conyzoides), to $10.76 \pm 3.55 \mu \mathrm{m}$ (in Cyanthillium cinereum). The pore shapes found in Asteraceae were rectangular and circular with the shortest diameter was $3.15 \pm 0.4 \mu \mathrm{m}$ (in Ageratum conyzoides) and the longest diameter was $4.81 \pm 1.03 \mu \mathrm{m}$ (in Porophyllum ruderale) (Table 4).

The owner of the smallest pollen in this group is Ageratum conyzoides, which grouped into medium pollen size, while the largest pollen size is owned by Elephantopus scaber, which grouped into wide pollen size (Table 1). The size of pollen was obtained by measuring the diameter of the pollen (Erdtman 1969).

Table 2 showed that pollens from all tribe members of Asteraceae family found in UI Campus had an isopolar polarity. All of pollen samples collected from the campus also had an isopolar radial symmetry with a single or monad pole unit. In addition, outer appearance of the pollen had a spheroidal shape, both in the polar and equatorial parts. The same is observed on the surface of pollen for the pollen of all collected species has an echinate or thorny surface. Since all above characters were similar in all tribes observed in this study, the polarity, symmetry, unity, outward (polar and equatorial) characters, and the surface of the pollen are good taxonomic features to be used in discriminating Asteraceae family from other families.

The comparison of aperture, pore and size characters from the tribe members of the Asteraceae family found in Campus of UI as a quantitative data are shown in Table 1 and Table 4. In our study, tribe Heliantheae and tribe Coreopsideae have the same aperture that is tricolporate. The result is in accordance with the statement by Stanski et al. (2013). Coreopsideae had previously been placed into a Coreopsidodinae super sub tribe in Heliantheae tribe in 2004. However, it has been revised by Jeffrey in 2007 into tribe Coreopsideae. He stated that Heliantheae tribe is closely related to Coreopsideae.

We found that Senecioneae, Millerieae, and Eupatorieae had tricolporate and tetracolporate aperture. According to Jeffrey (2007), Heliantheae and Coreopsideae tribes are in the same subfamily as the tribes Senecioneae, Millerieae, and Eupatorieae, under Asteroideae subfamily. This finding explained the kinship of those family members through aperture feature. Furthermore, the tribes Vernonieae and Cichorieae (both subfamily Chicorioideae; Jeffrey 2007) appeared to have fenestrate aperture. As a result, aperture character in this study can be used as a distinctive and decisive character in the kinship between subfamilies.

Observation of the pollen pore character showed that the pore shape of each species, even within one tribe, varied from circle to rectangle (Table 4). Tribe Heliantheae had one member with rectangular pores (Eclipta prostrata) and four species with circular pores. The members of Eupatorieae and Vernonieae tribes had unspecified pores.
According to The Australasian Pollen and Spore Atlas (APSA 2007), Ageratum conyzoides, Bidens pilosa, Emilia sonchifolia, and Tridax procumbens had pollen with rectangular to circular pores. The pores of Asteraceae were very diverse even within one tribe, therefore this character could not be used as a distinguishing character for its classification among tribes and species.

Pollen size in Asteraceae family was categorized as medium to wide, according to Erdtman's grouping (Erdtman 1969) (Table 1, Figure 1). The size of Elephantopus scaber pollen in this study was wide, whereas E. scaber pollen observed by Bunwong and Chantaranonthai (2008) was medium. Sphagneticola trilobata and Porophyllum ruderale were also showed different result from those measured by Octavia et al. (2015) that classify both species on a medium scale. While in our study, the two species have wide pollen size. The use of chemical treatment could be the cause of differences in pollen size. Prolonged exposure to chemicals such as acetolysis might affect the pollen size to shrink (Fægri and Iversen 1975). Moreover, the pollen sizes of species within one tribe also varied as in the Heliantheae Tribe which had one member (Sphagneticola trilobata) of wide size, and the other tribe members had medium size. Therefore, the size of pollen also could not be used as a distinguishing character between the tribes.

\section{ACKNOWLEDGEMENTS}

The authors gratefully acknowledge Universitas Indonesia Olympus Bioimaging Center (UOBC) Laboratory for the microscope facilities, and to Ms. Fatma Ayatiliulil who has assisted and provided support to researchers while conducting observation at UIOBC. Our thanks to Ms. Eka Ayu Ambarwati for her help in manuscript preparation. We also would like to thank the editors and the reviewers for their valuable suggestions and comments improved this paper.

\section{REFERENCES}

Al-Watban AA, Al-Mogren E, Doaigey AR, El-Zaidy M. 2013. Pollen morphology of seven wild species of Acacia in Saudi Arabia. African J Plant Sci 7 (12): 602-607.

Ambarwati EA. 2015. Chromosome number of some Asteraceae species at Universitas Indonesia, Depok. [Undergraduate Thesis]. Universitas Indonesia, Depok. [Indonesian]

Anderberg AA, Baldwin BG, Bayer RG, Breitwieser J, Jeffrey C, Dillon MO, Eldenäs P, Funk V, Garcia-Jacas N, Hind DJN, Karis PO, Lack HW, Nesom G, Nordenstam B, Oberprieler Ch, Panero JL, Puttock C, Robinson H, Stuessy TF, Susanna A, Urtubey E, Vogt R, Ward J, Watson LE. 2007. Compositae. In: Kadereit J, Jeffrey C (eds.). Flowering Plants, Eudicots: Asterales. Springer, Berlin.

Australasian Pollen and Spore Atlas (APSA). 2007. The Australasian pollen and spore atlas v.1.0. Australian National University, Canberra. http://apsa.anu.edu.au/

Barker MS, Li Z, Kidder TI, Reardon CR, Lai Z, Oliveira LO, Scascitelli M, Rieseberg LH. 2016. Most Compositae (Asteraceae) are descendants of a paleohexaploid and all share a paleotetraploid ancestor with the Calyceraceae. Amer J Bot 103 (7): 1203-1211.

Bentham G. 1873. Notes on the classification, history, and geographical distribution of Compositae. Bot J Linn Soc 13: 335-577. 
Blackmore S, Wortley AH, Skvarla JJ, Robinson H. 2009. Evolution of pollen in the Compositae. In: Funk VA, Susanna A, Stuessy TF, Bayer RJ (eds) Systematics, evolution and biogeography of Compositae. IAPT, Vienna.

Bremer K. 1987. Tribal interrelationship of the Asteraceae. Cladistics 3 (3): $210-253$

Bunwong S, Chantaranonthai P. 2008. Pollen morphology of the tribe Vernonieae (Compositae) in Thailand. Trop Nat Hist 8 (1): 45-55.

Cassini, A. H. G. 1817. Aperçu des genres formés par M. Cassini dans la famille des Synantherées. Troisième fascicule. Bulletin Scientifique, par la Société Philomatique de Paris 3: 31-34.

De Vore M, Zhao Z, Jansen RK, Skvarla JJ. 2007. Pollen morphology and ultrastructure of Calyceraceae. Lundellia 10: 32-48.

Erdtman G. 1969. Handbook of Palynology, An Introduction to the Study of Pollen Grains and Spores. Hafner Publishing Co., Munksgaard.

Fægri K, Iversen J. 1975. Textbook of Pollen Analysis. 3rd ed. Hafner Press, Munksgaard.

Feuer S. 1990. Pollen morphology of the Embothirieae (Proteaceae) II Embothriinae (Embothrium, Oreocallis, Telopea). Grana 29 (1): 1936.

Gustaffson MHG, Grafström E, Nilsson S. 1997. Pollen morphology of the Goodeniaceae and comparisons with related families. Grana 36 : 185-207.

Gustafsson MHG and Bremer K. 1995. Morphology and phylogenetic interrelationships of the Asteraceae, Calyceraceae, Campanulaceae, Goodeniaceae, and related families (Asterales). Amer J Bot 82 (2): 250-265.

Heywood VH. 1985. Flowering plants of the world. Croom Helm, London.

Jeffrey C. 2007. Compositae: Introduction with key to tribe. In: Kaderei J, Jeffrey C (eds.). Flowering Plants, Eudicots: Asterales. Springer, Heidelberg.

Kew Royal Botanic Garden. 2015. Compositae (Asteraceae) Retrieved from http://www.kew.org/science/compositae.html. [21 August 2015]

Khansari E, Zarre S, Alizadeh K, Attar F, Aghabeigi F, Salmaki Y. 2012. Pollen morphology of Campanula (Campanulaceae) and allied genera in Iran with special focus on its systematic implication. Flora 207 (3): 203-211.

Mbagwu FN, Chime EG, Unamba CIN. 2008. Palynological studies on five species of Asteraceae. J Plant Sci 3 (1): 126-129.

Octavia RS, Sulasmi ES, Sulisetijono. 2015. Pollen characterization of Asteraceae family in Malang Raya. Jurnal Online Universitas Negeri Malang 1: 1-9. [Indonesian].

Oktarina R. 2013. Species Description and Analysis Of Chromosomes Number on the Plant of Asteraceae family in University of Indonesia Depok [Hon. Thesis]. Universitas Indonesia, Depok, Indonesia. [Indonesian]

Panero, J.L., and Funk, V.A. 2008. The value of sampling anomalous taxa in phylogenetic studies: major clades of the Asteraceae revealed. Mol Phylogenet Evol 47 (2): 757-782.
Perveen A. 1999. Contributions to the pollen morphology of the family Compositae. Turkish J Biol 23: 523-535.

Perveen, A. and Qaiser, M. 2007. Pollen morphology of family Solanaceae from Pakistan. Pakistan J Bot 39 (7): 2243-2256.

Prihatiningsih R. 2011. Morphological, Anatomical, and Molecular Studies on Three Types of Flower Shape of Hibiscus rosa-sinensis L. at University of Indonesia, Depok. [Hon. Thesis]. Universitas Indonesia, Depok, Indonesia. [Indonesian]

Rismayanti, Triadiati, Raffiudin R. 2015. Ecology service of herbacious plants for Trigona's Bee. Jurnal Sumberdaya Hayati 1 (1): 19-25. [Indonesian]

Robinson H, Skvarla JJ. 2014. Pantoporate pollen in the Asteraceae (Vernonieae). PhytoKeys 38: 1-13.

Robinson H, Keeley SC, Skvarla JJ, Chan R. 2008. Studies on the Gymnantheminae (Vernonieae: Asteraceae) III: restoration of the genus Strobocalyx and the new genus Tarlmounia. Proc Biol Soc Washington 121 (1): 19-33.

Setyowati D. 2008. Tinjauan Taksonomi Family Asteraceae berdasarkan Sifat dan Ciri Morfologi Serbuk Sari. [Hon. Thesis]. Universitas Ahmad Dahlan, Yogyakarta, Indonesia. [Indonesian]

Song U, Park J, Song M. 2012. Pollen morphology of Pinus (Pinaceae) in Northeast China. For Sci Technol 8 (4): 179-186.

Stanski C, Luz CFP, Noguiera A, Noguiera MKFS. 2013. Palynology of species in the Astereae and Heliantheae tribes occuring in the region of Campos Gerais, Paraná State, Brazil. Iheringia Série Botanica 68 (2): 203-214

Sytwala S, Domsalla A, Melzig MF. 2015. Investigation of plant latices of Asteraceae and Campanulaceae regarding proteolytic activity. Plant Physiol Biochem 97:117-123.

Tjitrosoedirdjo SS. 2002. Notes on the Asteraceae of Sumatera. J Biotropia 19: 65-84.

Wang H, Wortley AH, Blackmore S. 2009. Pollen morphology of Crepidinae and Lactucinae (Asteraceae: Cichorieae) and its systematic significance. Grana 48 (3): 160-178.

Wortley AH, Blackmore S, Chissoe WF, Skvarla JJ. 2012. Recent advances in Compositae (Asteraceae) palynology, with emphasis on previously unstudied and unplaced taxa. Grana 51 (2): 158-179.

Wortley AH, Funk VA, Robinson HE, Skvarla JJ, Blackmore SH. 2007. A search for pollen morphological synapomorphies to classify rogue genera in Compositae (Asteraceae). Rev Palaeobot Palynol 146: 169181.

Wrońska-Pilarek D, Jagodziński AM, Bocianowski J, Janyszek M. 2015. The optimal sample size in pollen morphological studies using the example of Rosa canina L. (Rosaceae). Palynology 39 (1): 56-75.

Zavada M, Villiers S. 2000. Pollen of Asteraceae from the PaleoceneEocene of South Africa. Grana 39 (1): 39-45.

Zhao Z, Skvarla JJ, Jansen RK, DeVore ML. 2000. Phylogenetic Implications of pollen morphology and ultrastructure in the Barnadesioideae (Asteraceae). Lundellia 3 (1): 26-40. 